\title{
Gambaran Tingkat Kecemasan Anak Saat Perawatan Ekstraksi Gigi
}

\author{
Saskia E. Sekeon, ${ }^{1}$ Paulina N. Gunawan, ${ }^{1}$ Damajanty H. C. Pangemanan ${ }^{2}$
}

\author{
${ }^{1}$ Program Studi Pendidikan Dokter Gigi Fakultas Kedokteran Universitas Sam Ratulangi, \\ Manado, Indonesia \\ ${ }^{2}$ Bagian Fisiologi Fakultas Kedokteran Universitas Sam Ratulangi, Manado, Indonesia \\ Email: ekklesiasaskia@gmail.com
}

Disubmisi: 14 Oktober 2021; direvisi: 25 Oktober 2021; diterima: 26 Oktober 2021

\begin{abstract}
Going to a dentist can cause anxiety in children. One of dental treatments that causes anxiety is tooth extraction. This study was aimed to determine children's anxiety level during tooth extraction. This was a literature review study. Data were collected from the database of Google Scholar by using predefined keywords children's anxiety level and tooth extraction. Literatures were screened by title, and the inclusion and exclusion criteria. The critical appraisal was performed by using the Joanna Briggs Institute (JBI) critical appraisal and eight literatures weres obtained. The results showed that children's anxiety level during tooth extraction were anxiety and mild anxiety. Based on age, younger children were more anxious than older children. Based on gender, females were more anxious than males. In conclusion, during tooth extraction, the anxiety levels of most of the children were anxiety and mild anxiety.
\end{abstract}

Keywords: child anxiety level; tooth extraction

\begin{abstract}
Abstrak: Pemeriksaan kesehatan gigi dan mulut saat mengunjungi dokter gigi dapat menimbulkan kecemasan pada anak. Salah satu perawatan yang dapat menimbulkan kecemasan ialah ekstraksi gigi. Penelitian ini bertujuan untuk mengetahui gambaran tingkat kecemasan anak saat perawatan ekstraksi gigi. Jenis penelitian ialah literature review, Pencarian data pada database Google Scholar dengan menggunakan kata kunci tingkat kecemasan anak dan pencabutan gigi. Hasil pencarian dilakukan skrining berdasarkan judul, kriteria inklusi dan eksklusi, kemudian dilakukan uji kelayakan menggunakan the Joanna Briggs Institute (JBI) critical appraisal dan diperoleh delapan literatur. Hasil penelitian mendapatkan tingkat kecemasan anak saat perawatan ekstraksi gigi ialah cemas dan cemas ringan. Dilihat dari usia, anak lebih muda lebih cemas dibandingkan anak lebih tua. Dilihat dari jenis kelamin, anak perempuan lebih cemas daripada anak laki-laki. Simpulan penelitian ini ialah tingkat kecemasan sebagian besar anak pada saat perawatan ekstraksi gigi ialah cemas dan cemas ringan.
\end{abstract}

Kata kunci: tingkat kecemasan anak; ekstraksi gigi

\section{PENDAHULUAN}

Pemeriksaan kesehatan gigi dan mulut saat mengunjungi dokter gigi dapat menimbulkan gangguan emosional, dan yang paling sering muncul yaitu kecemasan. ${ }^{1}$ Kecemasan diartikan sebagai ketakutan pada sesuatu yang akan terjadi, rasa khawatir, dan gelisah. ${ }^{2}$ Kecemasan terhadap perawatan gigi disebut kecemasan dental atau dental anxiety. Pada anak, kecemasan dental memiliki estimasi prevalensi sekitar 6-20\% pada usia 4-18 tahun. ${ }^{3}$

Penelitian mengenai hubungan kecemasan anak usia 7-14 tahun dengan perawatan gigi yang dilakukan oleh Suryani et $\mathrm{al}^{4}$ menyatakan bahwa terdapat hubungan antara kecemasan anak dengan perawatan gigi. Aryani et $\mathrm{al}^{5}$ menyimpulkan bahwa anak usia 8-13 tahun yang terbanyak merasa sangat takut terhadap perawatan gigi, dan penyebab yang paling dominan ialah faktor internal dari anak. ${ }^{5}$ Pratami ${ }^{6}$ juga melakukan 
penelitian mengenai kecemasan dental dan menyimpulkan bahwa terdapat hubungan bermakna antara kecemasan dental anak usia 7-11 tahun dengan indeks karies.

Data riset kesehatan dasar (Riskesdas) tahun 2018 mencatat sebanyak 92,6\% anak usia 5-9 tahun mengalami karies; hal ini merupakan angka tertinggi di antara tiga kelompok usia anak. Sebanyak 28,5\% anak usia 5-9 tahun mengalami karies akar. Pada kelompok anak usia 10-14 tahun tercatat sebesar 73,4\% mengalami karies dan 48,1\% mengalami karies akar. ${ }^{7}$

Pada anak usia 6-14 tahun dapat dilakukan pencabutan gigi sulung atau gigi permanen karena pada rentang usia ini anak mulai memasuki periode gigi bercampur. Penelitian yang dilakukan oleh Rakhman et $\mathrm{al}^{8}$ di Manado terhadap kelompok anak usia 5-9 tahun melaporkan 105 kasus pencabutan gigi $(86,06 \%)$ dan pada kelompok anak usia 10 14 tahun terdapat 16 pencabutan $(13,13 \%)$. Penyebab pencabutan gigi anak yaitu karies gigi $(57,37 \%)$, mobilitas $(31,14 \%)$, dan persistensi $(11,49 \%)$. Hasil penelitian Fenanlampir et $\mathrm{al}^{9}$ di Langowan mendapatkan bahwa indikasi dilakukan tindakan pencabutan gigi pada anak usia 11-13 tahun yaitu persistensi sebesar 14\%, karies gigi sebesar $57,9 \%$, sisa akar sebesar 25,2\%, dan supernumerary teeth sebesar $2,7 \%$.

Berbagai hasil penelitian yang telah dipaparkan mendapatkan kasus ekstraksi gigi yang masih tinggi pada anak. Berdasarkan latar belakang ini maka penulis tertarik untuk menelusuri tingkat kecemasan anak saat perawatan pencabutan (ekstraksi) gigi.

\section{METODE PENELITIAN}

Penelitian ini merupakan suatu literature review. Data diperoleh dari database Google Scholar. Hasil pencarian diskrining berdasarkan kriteria inklusi yaitu jurnal dan artikel yang terbit dalam kurun waktu 10 tahun terakhir, tersedia dalam bentuk full text, menggunakan alat ukur Corah's dental anxiety scale (CDAS) dan facial image scale (FIS), populasi dan lokasi penelitian ialah anak dari berbagai daerah di Indonesia, berbahasa Inggris atau Indonesia sedangkan kriteria eksklusi yaitu isi jurnal tidak mencantumkan dengan jelas mengenai gambaran tingkat kecemasan anak saat pencabutan (ekstraksi) gigi. Hasil skrining diuji kelayakan menggunakan the Joanna Briggs Institute (JBI) critical appraisal.

\section{HASIL PENELITIAN}

Setelah melalui rangkaian skrining, diperoleh delapan literatur yang memenuhi kualifikasi. Tabel 1 memperlihatkan karakteristik dan ringkasan hasil artikel yang menjadi sumber penelitian ini.

Tabel 2 memperlihatkan distribusi lokasi dan populasi penelitian. Keseluruhan artikel berasal dari Indonesia dengan jumlah dan usia sampel beragam berkisar 6-13 tahun.

Tabel 3 memperlihatkan bahwa berdasarkan alat ukur FIS, tingkat kecemasan yang paling banyak ditunjukkan anak saat perawatan ekstraksi gigi ialah cemas.

Tabel 4 memperlihatkan bahwa berdasarkan alat ukur CDAS tingkat kecemasan yang ditunjukkan anak saat perawatan ekstraksi gigi ialah cemas ringan.

Tabel 5 memperlihatkan bahwa berdasarkan alat ukur FIS, kelompok anak usia 68 tahun paling banyak menunjukkan tingkat kecemasan cemas saat perawatan ekstraksi gigi. Kelompok anak usia 9-12 tahun terbagi dalam tingkat kecemasan tidak cemas, agak cemas, dan cemas. Anak usia 13 tahun paling banyak menunjukkan tingkat kecemasan agak cemas.

Tabel 6 memperlihatkan bahwa berdasarkan alat ukur CDAS, saat perawatan ekstraksi gigi anak usia 6-9 tahun terbanyak menunjukkan tingkat kecemasan tidak cemas dan cemas berat. Anak usia 10 tahun terbanyak menunjukkan tingkat kecemasan cemas sedang. Anak usia 11 tahun menunjukkan tingkat kecemasan cemas berat. Anak usia 12 tahun menunjukkan tingkat kecemasan bervariasi dari yang tidak cemas, cemas ringan, dan cemas berat.

Tabel 7 memperlihatkan bahwa berdasarkan alat ukur FIS, anak laki-laki menunjukkan tingkat kecemasan agak cemas sedangkan anak perempuan paling banyak mengalami tingkat kecemasan cemas saat 
perawatan ekstraksi gigi.

Tabel 8 memperlihatkan bahwa berdasarkan alat ukur CDAS, anak laki-laki terbanyak merasa tidak cemas sedangkan anak perempuan terbanyak mengalami cemas ringan saat perawatan ekstraksi gigi.

Tabel 1. Karakteristik literatur

\begin{tabular}{|c|c|c|c|c|}
\hline No & $\begin{array}{c}\text { Peneliti dan } \\
\text { Tahun }\end{array}$ & Judul & $\begin{array}{l}\text { Metode dan } \\
\text { Alat Ukur }\end{array}$ & Ringkasan Hasil \\
\hline 1 & $\begin{array}{l}\text { Rukmanawati, } \\
2019^{10}\end{array}$ & $\begin{array}{l}\text { Gambaran faktor-faktor pe- } \\
\text { nyebab kecemasan anak pada } \\
\text { tindakan pencabutan gigi di } \\
\text { Puskesmas Godean I }\end{array}$ & $\begin{array}{l}\text { Cross-sectional, } \\
\text { FIS }\end{array}$ & $\begin{array}{l}\text { Faktor-faktor yang menyebabkan kece- } \\
\text { masan adalah jenis kelamin }(64,7 \%) \text {, } \\
\text { usia }(47,8 \%) \text {, dan pengalaman berkun- } \\
\text { jung }(58,8 \%)\end{array}$ \\
\hline 2 & $\begin{array}{l}\text { Wijaya, } \\
2015^{11}\end{array}$ & $\begin{array}{l}\text { Hubungan kecemasan pasien } \\
\text { anak usia 6-13 tahun terhadap } \\
\text { pencabutan gigi di Puskesmas } \\
\text { Sumbersari Jember }\end{array}$ & $\begin{array}{l}\text { Cross-sectional, } \\
\text { FIS }\end{array}$ & $\begin{array}{l}\text { Pasien yang cemas memiliki resiko } 19 \\
\text { kali lipat untuk tidak melakukan pen- } \\
\text { cabutan gigi dibanding pasien yang } \\
\text { tidak cemas }\end{array}$ \\
\hline 3 & $\begin{array}{l}\text { Marwansyah } \\
\text { et al, } 2018^{12}\end{array}$ & $\begin{array}{l}\text { Tingkat kecemasan pada anak } \\
\text { dengan metode Corah's den- } \\
\text { tal anxiety scale (CDAS) di } \\
\text { Rumah Sakit Gigi dan Mulut } \\
\text { Baiturrah-mah Padang }\end{array}$ & $\begin{array}{l}\text { Cross-sectional, } \\
\text { CDAS }\end{array}$ & $\begin{array}{l}\text { Hasil penelitian diperoleh bahwa dari } \\
80 \text { responden, } 65 \text { responden anak } \\
\text { tingkat cemas sedang, } 13 \text { responden } \\
\text { tingkat cemas tinggi, dan } 2 \text { anak phobia }\end{array}$ \\
\hline 4 & $\begin{array}{l}\text { Rehatta et al, } \\
2014^{13}\end{array}$ & $\begin{array}{l}\text { Gambaran kecemasan penca- } \\
\text { butan gigi anak di Puskesmas } \\
\text { Bahu Manado }\end{array}$ & $\begin{array}{l}\text { Cross-sectional } \\
\text { CDAS }\end{array}$ & $\begin{array}{l}\text { Dari hasil penelitian didapatkan hasil } \\
\text { paling tinggi pada cemas berat yaitu } \\
\text { sebesar } 28 \text { sampel }(50,51 \%)\end{array}$ \\
\hline 5 & $\begin{array}{l}\text { Pramanto et } \\
\text { al, } 2017^{14}\end{array}$ & $\begin{array}{l}\text { Gambaran tingkat kecemasan } \\
\text { terhadap tindakan pencabutan } \\
\text { gigi anak kelas } 5 \text { di SD Kato- } \\
\text { lik Frater Don Bosco Manado }\end{array}$ & $\begin{array}{l}\text { Cross-sectional, } \\
\text { CDAS }\end{array}$ & $\begin{array}{l}\text { Tingkat kecemasan terhadap penca- } \\
\text { butan gigi pada anak paling banyak } \\
\text { pada kategori kecemasan ringan yaitu } \\
30 \text { anak }\end{array}$ \\
\hline 6 & $\begin{array}{l}\text { De Hersa et al, } \\
2012^{15}\end{array}$ & $\begin{array}{l}\text { Relation of anxiety and pulse } \\
\text { rate before tooth extraction of } \\
6-9 \text { years old children }\end{array}$ & Deskriptif, CDAS & $\begin{array}{l}\text { Terdapat hubungan kuat antara kece- } \\
\text { masan dengan denyut nadi sebelum } \\
\text { pencabutan gigi pada anak usia 6-9 } \\
\text { tahun }\end{array}$ \\
\hline 7 & $\begin{array}{l}\text { Balqis et al, } \\
2019^{16}\end{array}$ & $\begin{array}{l}\text { Hubungan pola asuh orangtua } \\
\text { dengan tingkat kecemasan } \\
\text { anak usia 6-12 tahun pada } \\
\text { tindakan pencabutan gigi }\end{array}$ & $\begin{array}{l}\text { Cross-sectional, } \\
\text { FIS }\end{array}$ & $\begin{array}{l}\text { Pola asuh orangtua demokratif tidak } \\
\text { berhubungan dengan tingkat kece- } \\
\text { masan anak, sedangkan pola asuh } \\
\text { otoriter dan permisif berhubungan } \\
\text { dengan tingkat kecemasan anak dalam } \\
\text { tindakan pencabutan gigi }\end{array}$ \\
\hline 8 & $\begin{array}{l}\text { Fernanda et al, } \\
2019^{17}\end{array}$ & $\begin{array}{l}\text { Perbedaan tingkat kecemasan } \\
\text { dan Facial Image Scale (FIS) } \\
\text { pada anak yang akan mengha- } \\
\text { dapi tindakan pencabutan dan } \\
\text { penumpatan gigi di Puskes- } \\
\text { mas Depok Unit III }\end{array}$ & $\begin{array}{l}\text { Cross-sectional, } \\
\text { FIS }\end{array}$ & $\begin{array}{l}\text { Tingkat kecemasan pada anak yang } \\
\text { akan menghadapi tindakan penumpat- } \\
\text { an sebanyak } 24 \text { responden kriteria } \\
\text { tidak cemas dan FIS pada anak yang } \\
\text { akan menghadapi tindakan pencabutan } \\
\text { sebanyak } 26 \text { responden kriteria cemas }\end{array}$ \\
\hline
\end{tabular}

FIS: Facial Image Scale, CDAS: Corah's Dental Anxiety Scale

Tabel 2. Distribusi lokasi dan populasi penelitian

\begin{tabular}{cllcc}
\hline No. & \multicolumn{1}{c}{ Peneliti } & \multicolumn{1}{c}{ Lokasi } & Jumlah Sampel & Usia Sampel (tahun) \\
\hline 1 & Rukmanawati $^{10}$ & Sleman, Indonesia & 30 & $7-10$ \\
2 & Wijaya $^{11}$ & Jember, Indonesia & 77 & $6-13$ \\
3 & Marwansyah et al $^{12}$ & Padang, Indonesia & 17 & $6-12$ \\
4 & ${\text { Rehatta et } \text { al }^{13}}^{14}$ & Manado, Indonesia & 55 & $6-12$ \\
5 & Pramanto et al $^{14}$ & Manado, Indonesia & 68 & Anak kelas 5 SD \\
6 & De Hersa et al $^{15}$ & Bandung, Indonesia & 30 & $6-9$ \\
7 & Balqis et al $^{16}$ & Jogjakarta, Indonesia & 47 & $6-12$ \\
8 & Fernanda et al $^{17}$ & Sleman, Indonesia & 30 & $6-13$ \\
\hline
\end{tabular}


Tabel 3. Gambaran tingkat kecemasan berdasarkan FIS

\begin{tabular}{|c|c|c|c|c|c|c|c|c|c|c|c|c|c|}
\hline \multirow[t]{2}{*}{ No } & \multirow[t]{2}{*}{ Peneliti } & \multicolumn{2}{|c|}{$\begin{array}{c}\text { Sangat } \\
\text { tidak } \\
\text { cemas }\end{array}$} & \multicolumn{2}{|c|}{$\begin{array}{l}\text { Tidak } \\
\text { cemas }\end{array}$} & \multicolumn{2}{|c|}{$\begin{array}{l}\text { Agak } \\
\text { cemas }\end{array}$} & \multicolumn{2}{|c|}{ Cemas } & \multicolumn{2}{|c|}{$\begin{array}{l}\text { Sangat } \\
\text { cemas }\end{array}$} & \multicolumn{2}{|c|}{ Total } \\
\hline & & $\mathrm{n}$ & $\%$ & $\mathrm{n}$ & $\%$ & $\mathrm{n}$ & $\%$ & $\mathrm{n}$ & $\%$ & $\mathrm{n}$ & $\%$ & $\mathrm{n}$ & $\%$ \\
\hline 1 & Rukmanawati ${ }^{10}$ & 3 & 10 & 3 & 10 & 6 & 20 & 14 & 46,7 & 4 & 13,3 & 30 & 100 \\
\hline 2 & Wijaya $^{11}$ & 7 & 9,1 & 5 & 6,5 & 44 & 57,1 & 14 & 18,2 & 7 & 9,1 & 77 & 100 \\
\hline 3 & Balqis et $\mathrm{al}^{16}$ & 0 & 0 & 21 & 44,7 & 0 & 0 & 26 & 55,3 & 0 & 0 & 47 & 100 \\
\hline 4 & Fernanda et $\mathrm{al}^{17}$ & 0 & 0 & 4 & 6 & 0 & 0 & 26 & 43,3 & 0 & 0 & 30 & 100 \\
\hline
\end{tabular}

Tabel 4. Gambaran tingkat kecemasan berdasarkan CDAS

\begin{tabular}{clccccccccccc}
\hline \multirow{2}{*}{ No } & \multirow{2}{*}{ Peneliti } & \multicolumn{2}{c}{ Tidak cemas } & \multicolumn{2}{c}{$\begin{array}{c}\text { Cemas } \\
\text { ringan }\end{array}$} & \multicolumn{2}{c}{$\begin{array}{c}\text { Cemas } \\
\text { sedang }\end{array}$} & \multicolumn{2}{c}{$\begin{array}{c}\text { Cemas } \\
\text { berat }\end{array}$} & \multicolumn{2}{c}{ Total } \\
& & & $\mathrm{n}$ & $\%$ & $\mathrm{n}$ & $\%$ & $\mathrm{n}$ & $\%$ & $\mathrm{n}$ & $\%$ & $\mathrm{n}$ & $\%$ \\
\hline 1 & Marwansyah et al $^{12}$ & 0 & 0 & 11 & 64,7 & 5 & 29,4 & 1 & 5,8 & 17 & 100 \\
2 & Rehatta et al $^{13}$ & 7 & 12,73 & 10 & 18,18 & 10 & 18,18 & 28 & 50,91 & 55 & 100 \\
3 & Pramanto et al $^{14}$ & 24 & 35,30 & 30 & 44,12 & 8 & 11,76 & 6 & 8,82 & 68 & 100 \\
4 & De Hersa et al $^{15}$ & 27 & 90 & 0 & 0 & 1 & 3,3 & 2 & 6,7 & 30 & 100 \\
\hline
\end{tabular}

Tabel 5. Gambaran tingkat kecemasan dilihat dari usia anak berdasarkan FIS

\begin{tabular}{|c|c|c|c|c|c|c|c|c|c|c|c|c|c|c|}
\hline \multirow[t]{2}{*}{ No } & \multirow[t]{2}{*}{ Peneliti } & \multirow[t]{2}{*}{ Usia } & \multicolumn{2}{|c|}{$\begin{array}{l}\text { Sangat } \\
\text { tidak } \\
\text { cemas }\end{array}$} & \multicolumn{2}{|c|}{$\begin{array}{l}\text { Tidak } \\
\text { cemas }\end{array}$} & \multicolumn{2}{|c|}{$\begin{array}{l}\text { Agak } \\
\text { cemas }\end{array}$} & \multicolumn{2}{|c|}{ Cemas } & \multicolumn{2}{|c|}{$\begin{array}{l}\text { Sangat } \\
\text { cemas }\end{array}$} & \multicolumn{2}{|c|}{ Total } \\
\hline & & & $\mathrm{n}$ & $\%$ & $\mathrm{n}$ & $\%$ & $\mathrm{n}$ & $\%$ & $\mathrm{n}$ & $\%$ & $\mathrm{n}$ & $\%$ & $\mathrm{n}$ & $\%$ \\
\hline \multirow[t]{2}{*}{1} & Rukmanawati $^{10}$ & $7-8$ & 2 & 8,7 & 2 & 8,7 & 4 & 17,4 & 11 & 47,8 & 4 & 17,4 & \multirow{2}{*}{30} & \multirow{2}{*}{100} \\
\hline & & $9-10$ & 1 & 14,3 & 1 & 14,3 & 2 & 28,6 & 3 & 42,9 & 0 & 0 & & \\
\hline \multirow[t]{3}{*}{2} & Wijaya $^{11}$ & $6-8$ & 4 & 8,1 & 1 & 2 & 27 & 55,1 & 11 & 22,4 & 6 & 12,3 & & \\
\hline & & $9-12$ & 2 & 8,7 & 4 & 17,4 & 14 & 60,9 & 2 & 8,7 & 1 & 4,3 & 77 & 100 \\
\hline & & 13 & 1 & 20 & 0 & 0 & 3 & 60 & 1 & 20 & 0 & 0 & & \\
\hline \multirow[t]{2}{*}{3} & Balqis et $\mathrm{al}^{16}$ & $6-8$ & 0 & 0 & 8 & 38,1 & 0 & 0 & 15 & 57,7 & 0 & 0 & 47 & 100 \\
\hline & & $9-12$ & 0 & 0 & 13 & 61,9 & 0 & 0 & 11 & 42,3 & 0 & 0 & & \\
\hline
\end{tabular}

Tabel 6. Gambaran tingkat kecemasan dilihat dari usia anak berdasarkan CDAS

\begin{tabular}{|c|c|c|c|c|c|c|c|c|c|c|c|c|}
\hline \multirow[t]{2}{*}{ No } & \multirow{2}{*}{ Peneliti } & \multirow{2}{*}{$\underset{\text { (tahun) }}{\text { Usia }}$} & \multicolumn{2}{|c|}{$\begin{array}{l}\text { Tidak } \\
\text { cemas }\end{array}$} & \multicolumn{2}{|c|}{$\begin{array}{l}\text { Cemas } \\
\text { ringan }\end{array}$} & \multicolumn{2}{|c|}{$\begin{array}{l}\text { Cemas } \\
\text { sedang }\end{array}$} & \multicolumn{2}{|c|}{$\begin{array}{c}\text { Cemas } \\
\text { berat }\end{array}$} & \multicolumn{2}{|c|}{ Total } \\
\hline & & & $\mathrm{n}$ & $\%$ & $\mathrm{n}$ & $\%$ & $\mathrm{n}$ & $\%$ & $\mathrm{n}$ & $\%$ & $\mathrm{n}$ & $\%$ \\
\hline \multirow[t]{7}{*}{1} & Rehatta et $\mathrm{al}^{13}$ & 6 & 0 & 0 & 1 & 25 & 1 & 25 & 2 & 50 & \multirow{7}{*}{55} & \multirow{7}{*}{100} \\
\hline & & 7 & 0 & 0 & 3 & 25 & 1 & 8,3 & 8 & 66,7 & & \\
\hline & & 8 & 1 & 11,1 & 0 & 0 & 3 & 33,3 & 5 & 55,6 & & \\
\hline & & 9 & 1 & 8,3 & 3 & 25 & 2 & 16,7 & 6 & 50 & & \\
\hline & & 10 & 1 & 25 & 0 & 0 & 2 & 50 & 1 & 25 & & \\
\hline & & 11 & 2 & 25 & 1 & 12,5 & 1 & 12,5 & 4 & 50 & & \\
\hline & & 12 & 2 & 33,3 & 2 & 33,3 & 0 & 0 & 2 & 33,3 & & \\
\hline \multirow[t]{4}{*}{2} & De Hersa etal ${ }^{15}$ & 6 & 8 & 88,9 & 0 & 0 & 0 & 0 & 1 & 11,1 & \multirow{4}{*}{30} & \multirow{4}{*}{100} \\
\hline & & 7 & 9 & 100 & 0 & 0 & 0 & 0 & 0 & 0 & & \\
\hline & & 8 & 3 & 60 & 0 & 0 & 1 & 20 & 1 & 20 & & \\
\hline & & 9 & 7 & 100 & 0 & 0 & 0 & 0 & 0 & 0 & & \\
\hline
\end{tabular}


Tabel 7. Gambaran tingkat kecemasan dilihat dari jenis kelamin berdasarkan FIS

\begin{tabular}{|c|c|c|c|c|c|c|c|c|c|c|c|c|c|c|}
\hline \multirow[t]{2}{*}{ No } & \multirow[t]{2}{*}{ Peneliti } & \multirow{2}{*}{$\begin{array}{c}\text { Jenis } \\
\text { kelamin }\end{array}$} & \multicolumn{2}{|c|}{$\begin{array}{c}\text { Sangat } \\
\text { tidak cemas }\end{array}$} & \multicolumn{2}{|c|}{$\begin{array}{l}\text { Tidak } \\
\text { cemas }\end{array}$} & \multicolumn{2}{|c|}{$\begin{array}{l}\text { Agak } \\
\text { cemas }\end{array}$} & \multicolumn{2}{|c|}{ Cemas } & \multicolumn{2}{|c|}{$\begin{array}{c}\text { Sangat } \\
\text { cemas }\end{array}$} & \multicolumn{2}{|c|}{ Total } \\
\hline & & & $\mathrm{n}$ & $\%$ & $\mathrm{n}$ & $\%$ & $\mathrm{n}$ & $\%$ & $\mathrm{n}$ & $\%$ & $\mathrm{n}$ & $\%$ & $\mathrm{n}$ & $\%$ \\
\hline \multirow[t]{2}{*}{1} & \multirow{2}{*}{$\begin{array}{l}\text { Rukma- } \\
\text { nawati }^{10}\end{array}$} & Laki-laki & 3 & 23,1 & 3 & 23,1 & 3 & 23,1 & 3 & 23,1 & 1 & 13 & \multirow[b]{2}{*}{30} & \multirow{2}{*}{100} \\
\hline & & Perempuan & 0 & 0 & 0 & 0 & 3 & 17,6 & 11 & 64,7 & 3 & 17,6 & & \\
\hline \multirow[t]{2}{*}{2} & \multirow[t]{2}{*}{ Wijaya $^{11}$} & Laki-laki & 3 & 3,9 & 3 & 3,9 & 21 & 27,3 & 8 & 10,4 & 2 & 2,6 & \multirow{2}{*}{77} & \multirow{2}{*}{100} \\
\hline & & Perempuan & 4 & 5,2 & 2 & 2,6 & 23 & 29,9 & 6 & 7,8 & 5 & 6,5 & & \\
\hline \multirow[t]{2}{*}{3} & \multirow{2}{*}{$\begin{array}{l}\text { Balqis et } \\
\mathrm{al}^{16}\end{array}$} & Laki-laki & 0 & 0 & 9 & 45 & 0 & 0 & 11 & 55 & 0 & 0 & \multirow[b]{2}{*}{47} & \multirow[b]{2}{*}{100} \\
\hline & & Perempuan & 0 & 0 & 12 & 44,4 & 0 & 0 & 15 & 55,6 & 0 & 0 & & \\
\hline
\end{tabular}

Tabel 8. Gambaran tingkat kecemasan dilihat dari jenis kelamin berdasarkan CDAS

\begin{tabular}{|c|c|c|c|c|c|c|c|c|c|c|c|c|}
\hline \multirow[t]{2}{*}{ No } & \multirow[t]{2}{*}{ Peneliti } & \multirow{2}{*}{$\begin{array}{c}\text { Jenis } \\
\text { kelamin }\end{array}$} & \multicolumn{2}{|c|}{$\begin{array}{l}\text { Tidak } \\
\text { cemas }\end{array}$} & \multicolumn{2}{|c|}{$\begin{array}{l}\text { Cemas } \\
\text { ringan }\end{array}$} & \multicolumn{2}{|c|}{$\begin{array}{l}\text { Cemas } \\
\text { sedang }\end{array}$} & \multicolumn{2}{|c|}{$\begin{array}{c}\text { Cemas } \\
\text { berat }\end{array}$} & \multicolumn{2}{|c|}{ Total } \\
\hline & & & $\mathrm{n}$ & $\%$ & $\mathrm{n}$ & $\%$ & $\mathrm{n}$ & $\%$ & $\mathrm{n}$ & $\%$ & $\mathrm{n}$ & $\%$ \\
\hline \multirow[t]{2}{*}{1} & \multirow{2}{*}{$\begin{array}{l}\text { Rehatta et } \\
\mathrm{al}^{13}\end{array}$} & Laki-laki & 4 & 7,27 & 7 & 12,73 & 3 & 5,45 & 13 & 23,64 & 55 & 100 \\
\hline & & Perempuan & 3 & 5,45 & 3 & 5,45 & 7 & 12,73 & 15 & 27,27 & & \\
\hline 2 & $\begin{array}{l}\text { Pramanto } \\
\text { at } \mathrm{al}^{14}\end{array}$ & Laki-laki & 16 & 50 & 11 & 34,38 & 3 & 9,37 & 2 & 6,25 & 68 & 100 \\
\hline
\end{tabular}

\section{BAHASAN}

Telah diakui bahwa kecemasan dental pada anak merupakan sebuah masalah yang terjadi selama bertahun-tahun dan menyebabkan anak berperilaku tidak kooperatif seperti menunda atau bahkan membatalkan dan menolak untuk melakukan perawatan gigi. ${ }^{18}$ Tindakan pencabutan atau ekstraksi gigi dinyatakan sebagai penyebab kecemasan dental paling tinggi pada anak. ${ }^{19}$

Dari delapan literatur yang diteliti, terdapat empat literatur yang menggunakan FIS sebagai alat ukur dan empat literatur lainnya menggunakan CDAS. Penelitian mengenai tingkat kecemasan saat ekstraksi gigi dengan menggunakan alat ukur FIS salah satunya ialah penelitian oleh Rukmanawati ${ }^{10}$ di Sleman yang menyatakan bahwa anak-anak paling banyak menunjukkan tingkat kecemasan cemas. Penelitian serupa juga dilakukan oleh Fernanda et $\mathrm{al}^{17}$ di Sleman dan memperoleh hasil yang sama, yaitu saat perawatan ekstraksi gigi anakanak paling banyak menunjukkan tingkat kecemasan cemas.

Pada literatur yang menggunakan alat ukur CDAS, dua literatur melaporkan hasil yang sama yaitu penelitian oleh Marwansyah $^{12}$ di Padang dan penelitian oleh Pra- manto et $\mathrm{al}^{14}$ di Manado yang menyata-kan bahwa anak-anak paling banyak menunjukkan tingkat kecemasan cemas ringan. Hal ini sejalan dengan penelitian oleh Simaremare et $\mathrm{al}^{20}$ yang mendapatkan bahwa terbanyak anak merasa cemas ringan terhadap tindakan pencabutan gigi.

Rasa cemas yang dialami anak saat hendak melangsungkan perawatan gigi dipengaruhi oleh dua faktor, yaitu eksternal dan internal. Faktor internal adalah faktor yang stimulusnya berasal dari dalam diri anak, salah satunya ialah usia anak. ${ }^{21}$

Dari tiga literatur yang membahas distribusi tingkat kecemasan berdasarkan usia anak menggunakan alat ukur FIS diperoleh bahwa saat perawatan ekstraksi gigi, kelompok anak berusia 6-8 tahun paling banyak mengalami tingkat kecemasan cemas. Pada kelompok usia 9-12 tahun, tingkat kecemasan anak terbagi ke tingkatan tidak cemas, agak cemas dan cemas. Selanjutnya, penelitian oleh Wijaya ${ }^{11}$ yang juga mengambil sampel anak berusia 13 tahun, menunjukkan bahwa anak mengalami tingkat kecemasan agak cemas saat perawatan ekstraksi gigi.

Keseluruhan literatur yang menggunakan alat ukur CDAS menunjukkan bahwa 
anak usia 6-9 tahun paling banyak mengalami tidak cemas dan cemas berat, anak usia 10 tahun mengalami cemas sedang. Anak usia 11 tahun sebanyak 4 orang mengalami cemas berat, namun terdapat 2 orang yang tidak merasa cemas sama sekali; hal ini merupakan angka tertinggi di kategori tidak cemas. Pada anak usia 12 tahun didapatkan tingkat kecemasan beragam dan menunjukkan jumlah sama yang tersebar di kategori tidak cemas, cemas ringan, dan cemas berat, yang berarti bahwa semakin bertambahnya usia anak, tingkat kecemasan semakin menurun. Hal ini sejalan dengan penelitian Malihah et $\mathrm{al}^{22}$ yang menyatakan bahwa semakin bertambah usia anak maka tingkat kecemasan akan semakin menurun karena sedikitnya pengalaman yang dimiliki oleh anak dengan usia lebih muda jika dibandingkan dengan anak yang lebih tua. Hal ini juga disebabkan karena dengan bertambahnya usia, anak semakin mampu untuk mengevaluasi keadaan atau kondisi yang dialaminya. ${ }^{22}$

Jenis kelamin juga merupakan salah satu faktor internal yang berpengaruh pada tingkat kecemasan anak. ${ }^{23,24}$ Dari literatur yang menggunakan FIS didapatkan bahwa anak laki-laki paling banyak merasa agak cemas dan anak perempuan paling banyak mengalami cemas saat perawatan ekstraksi gigi. Pada dua literatur dengan pengukuran kecemasan saat perawatan ekstraksi gigi menggunakan alat ukur CDAS diperoleh hasil yaitu anak laki-laki paling banyak merasa tidak cemas dan anak perempuan paling banyak mengalami cemas ringan. Hasil ini sejalan dengan penelitian Sanger et $\mathrm{al}^{25}$ di Manado yang menyebutkan bahwa pada anak perempuan ditemukan tingkat kecemasan yang lebih tinggi jika dibandingkan anak laki-laki, karena anak perempuan lebih intens mengekspresikan rasa nyeri dan memiliki ketahanan terhadap rasa sakit yang lebih rendah dibandingkan anak laki-laki. ${ }^{25}$

\section{SIMPULAN}

Sebagian besar anak-anak mengalami tingkat kecemasan cemas dan cemas ringan saat perawatan ekstraksi gigi.

\section{Konflik Kepentingan}

Penulis menyatakan bahwa tidak terdapat konflik kepentingan dalam studi ini.

\section{DAFTAR PUSTAKA}

1. Lombardo G, Lupatelli E, Pagano S, Abraha I. Dental fear/anxiety among children and adolescents. Eur J Paediat Dent. 2017; 18(2): 121.

2. Agarwal M, Das UM. Dental anxiety prediction using Venham Picture test: a preliminary cross-sectional study. J Indian Soc Pedod Prev Dent. 2013;31(1):22-4.

3. Morgan AG, Rodd HD, Porritt JM, Baker SR, Creswell C, Newton T, et al. Children's experiences of dental anxiety. Int $\mathrm{J}$ Paediatr Dent. 2017;27(2):87-97.

4. Suryani L. Hubungan kecemasan anak usia 714 tahun dengan perawatan gigi di Poli Gigi Puskesmas Indrapuri. Prosiding Seminar Nasional Multi Disiplin Ilmu Unaya. 2019;3(1);77-86.

5. Aryani DD, Gartika M, Hidayat S. Eight to thirteen years old children fear at dental treatment. Padjadjaran J Dent (Bdg). 2013;25(2):104-7.

6. Pratami PFS, Prasetya MA, Marheni A. Hubungan kecemasan dental anak umur 7-11 tahun dengan indeks karies di SD Negeri 27 Pemecutan Denpasar Barat. Bali Dental Journal. 2018;2(1):37-43.

7. Kementerian Kesehatan RI. Faktor risiko kesehatan gigi dan mulut. Pusat Data dan Informasi Kementerian Kesehatan RI. 2019; p. 1-10.

8. Rakhman DN, Lampus BS, Mariati NW. Gambaran karakteristik dan penyebab pencabutan gigi sulung di Puskesmas Paniki Bawah Kota Manado pada tahun 2012. e-GiGi. 2015;3(1):170-2.

9. Fenanlampir IJ, Mariati NW, Hutagalung B. Gambaran indikasi pencabutan gigi dalam periode gigi bercampur pada siswa SMP Negeri 1 Langowan. e-GiGi. 2014;2(2).

10. Rukmanawati F. Gambaran faktor-faktor yang menyebabkan kecemasan anak pada tindakan pencabutan gigi di Puskesmas Godean I [Diploma Tesis]. Yogyakarta: Politeknik Kesehatan Ke-menterian Kesehatan Yogyakarta: 2019.

11. Wijaya AL. Hubungan kecemasan pasien anak usia 6-13 tahun terhadap pencabut-an gigi di Puskesmas Sumber Sari Jem-ber. Pustaka Kesehatan. 2015;3(2):8-9. 
12. Marwansyah, Mahata IBE, Elianora D. Tingkat kecemasan pada anak dengan metode Corah's Dental Anxiety Scale (CDAS) di Rumah Sakit Gigi dan Mulut Baiturrahmah Padang. Jurnal B-Dent. 2018;5:20-9.

13. Rehatta VC, Kandou J, Gunawan PN. Gambaran kecemasan pencabutan gigi anak di Puskesmas Bahu Manado. eGiGi. 2014;2(2).

14. Pramanto R, Munayang H, Hutagalung BSP. Gambaran tingkat kecemasan ter-hadap tindakan pencabutan gigi anak kelas 5 SD di SD Katolik Frater Don Bosco Manado. Pharmacon. 2017;6(4): 201-6.

15. De Hersa SCRA, Herdiyati Y, Tjahajawati S. Relation of anxiety and pulse rate before tooth exctraction of 6-9 years old children. Padjadjaran J Dent (Bdg). 2012;24(2):148-52.

16. Balqis IZ, Sulistyani H, Yuniarly E. Hubungan pola asuh orangtua dengan tingkat kecemasan anak usia 6-12 tahun pada tindakan pencabutan gigi. Journal of Oral Health Care. 2019;7(1):16-23.

17. Fernanda R, Quroti A, Purwati DE. Perbedaan tingkat kecemasan dan facial image scale (FIS) pada anak yang akan menghadapi tindakan pencabutan dan penumpatan gigi di Puskesmas Depok Unit III. Journal of Oral Health Care. 2019;7(2):55-65.

18. Reca, Putri CF, Salfiyadi T, Nuraskin CA, Mardiah A. Tingkat kecemasan anak dalam pencabutan gigi di Puskesmas Mutiara. Jurnal Online Keperawatan Indones. 2020;3(1):9-14.

19. Mathius NPNE, Sembiring L, Rohinsa M. Tingkat kecemasan dental anak usia 7-
12 tahun yang akan melakukan ekstraksi gigi di RSGM Maranatha. Padjadjaran J Dent Res Students. 2019;3(1):33-42.

20. Simaremare RT, Rosma M, Yulia R. Gambaran tingkat kecemasan anak usia 6-8 tahun terhadap pencabutan gigi di klinik Jurusan Keperawatan Gigi Tahun 2016. J Ilm PANNMED (Pharmacist, Anal Nurse, Nutr Midwivery, Environ Dent. 2018;11(3):187-95

21. Koch G, Poulsen S, Espelid I, Haubek D. Pediatric Dentistry: A Clinical Approach. (3rd ed). Chichester: Wiley, 2017; p. 157-65.

22. Malihah DT, Sasmita IS, Setiawan ASPP. Korelasi peran modelling orang tua pada saat pelaksanaan perawatan kesehatan gigi dengan dental fear anak. Padjadjaran J Dent Res Students. 2018;2(1):31.

23. Kristiana Dewi M, Aditya Handoko S, Nugrahaeni Widiasavitri P. Faktorfaktor yang memengaruhi kecemasan dental pada anak usia 8-12 tahun di Sekolah Dasar Negeri 3 Peguyangan Denpasar. Bali Dental Journal. 2020; 4(1):13-20.

24. Hamudeng AM, Ryanda FR. Anxiety level differentiation in 6-12 years old children before and after loss dental care using topical anesthesia at Dental Hospital Hasanuddin University. Journal of Dentomaxillofacial Science. 2016;1(3): 166-70.

25. Sanger SE, Pangemanan DHC, Leman MA. Gambaran kecemasan anak usia 6-12 tahun terhadap perawatan gigi di SD Kristen Eben Haezar 2 Manado. e-GiGi. 2017;5(2):190-6. 